\title{
Tinjauan Yuridis Transaksi Financial Technology di Indonesia
}

\author{
Alfi Fratiwi \\ Program Studi Hukum, Fakultas Hukum, Universitas Muhammadiyah Yogyakarta, Indonesia \\ Korespondensi: alfi.fratiwi.2016@law.umy.ac.id
}

Info Artikel

Diajukan: 28 September 2021

Direview: 29 September 2021

Direvisi: 04 Oktober 2021

Diterima: 04 Oktober 2021

DOI: $10.18196 / \mathrm{mls} . v 2 i 4.12828$

\begin{abstract}
Abstrak
Kemajuan teknologi informasi dan komunikasi menawarkan berbagai macam produk guna memudahkan kehidupan manusia, termasuk bidang keuangan atau finansial. Layanan jasa keuangan yang pada umumnya dilakukan oleh lembaga keuangan baik bank maupun bukan bank serta lembaga pembiayaan, kini dapat dilakukan hanya dengan bantuan gawai dan media internet. Inovasi di bidang keuangan ini dikenal dengan financial technology (fintech), yang dalam
\end{abstract} bahasa Indonesia disebut teknologi finansial. Keberadaan fintech sendiri di Indonesia telah diakui serta diatur dalam Peraturan Bank Indonesia Nomor 19/12/PBI/2017 tentang Penyelenggaraan Teknologi Finansial. Akan tetapi dalam aturan tersebut tidak dijelaskan mengenai kedudukan para pihak dalam transaksi financial technology. Tujuan penelitian ini adalah untuk mengetahui tentang tinjauan yuridis terkait transaksi financial technology di Indonesia serta kedudukan para pihak dalam transaksi tersebut. Metode penelitian yang penulis gunakan adalah jenis penelitian hukum yuridis normative yang dianalisis dengan metode analisis deskriptif kualitatif. Hasil penelitian ini menunjukkan bahwa belum adanya aturan mengenai kedudukan para pihak yang sudah jelas terdapat dalam hak dan kewajiban yang dimiliki oleh masing-masing pihak serta penyelenggara harus terdaftar dalam OJK serta menerapkan prinsip perlindungan konsumen, kerahasiaan data, manajemen resiko dan kehati-hatian menggunakan rupiah dan anti pencucian uang serta bertanggung jawab untuk menyediakan dan/ atau menyampaikan informasi terkini mengenai transaksi financial technology dengan secara jelas dan jujur.

Kata kunci: financial technology; kedudukan para pihak; tinjauan yuridis

\section{Pendahuluan}

Financial Technology (Fintech) muncul seiring dengan perubahan gaya hidup masyarakat yang saat ini didominasi oleh penggunaan teknologi informasi tuntutan hidup yang serba cepat. ${ }^{1}$ Masuknya teknologi informasi ke industri keuangan Indonesia ditandai dengan munculnya momentum transformasi di dunia finansial, dimana antara peminjam dan pemberi pinjaman tidak perlu lagi bertatap muka secara konvensional, namun cukup bertemu lewat dunia maya yang dihubungkan oleh internet. ${ }^{2}$ Fintech berasal dari istilah financial technology atau teknologi finansial. Menurut The National Digital Research Centre (NDRC), di Dublin, Irlandia, mendefinisikan fintech sebagai "innovation in financial services" atau "inovasi dalam layanan keuangan fintech" yang merupakan suatu

\footnotetext{
${ }^{1}$ Rahadi, D. R. (2020). Financial Technology. PT: Filda Fikrindo.

${ }^{2}$ Adiningsih, S. (2019). Transformasi Ekonomi Berbasis Digital di Indonesia. Jakarta: PT Gramedia Pustaka Utama.
} 
inovasi pada sektor finansial yang mendapat sentuhan teknologi modern. ${ }^{3}$ Transaksi keuangan melalui fintech ini meliputi pembayaran, investasi, peminjaman uang, transfer, rencana keuangan dan pembanding produk keuangan. Saat ini terdapat 142 perusahaan yang bergerak dibidang fintech yang teridentifikasi beroprasi di Indonesia. Beberapa perusahan fintech yang telah ada di Indonesia saat ini, misalnya CekAja, UangTeman, Pinjam, CekPremi, Bareksa, Kartuku. Dengan adanya keberadaan Fintech dapat mendatangankan proses transaksi keuangan yang lebih praktis. ${ }^{4}$

Selain itu didalam inovasinya fintech menyediakan bermacam pilihan layanan bagi penggunan, mulai dari efisiensi dan keamanan pembayaran, hingga aksesibilitas layanan keuangan yang lebih baik. ${ }^{5}$ Industri fintech dianggap lebih fleksibel dibandingkan dengan bisnis keuangan konvensional atau bank tradisional dimana masih terbatasanya peraturan yang mengatur industri keuangan ini. ${ }^{6}$ Hal tersebut terlihat pada saat proses pengajuan pinjaman pasa jasa keuangan kovensional, dengan beragam proses administrasi yang harus dilengkapi. Berbeda dengan bisnis fintech, kelengkapan berkas yang dibutuhkan hanya sedikit dan dapat dilakukan melalui internet hanya dengan mengunggah dokumen yang dibutuhkan. Di Indonesia sendiri fintech begitu familiar dengan berbagai alasan, yaitu: ${ }^{7}$

a. Semakin meluasnya penggunaan internet dan smartphone, sehingga dibutuhkan transaksi keuangan secara online;

b. Fintech lebih memudahkan berbagai proses dalam bidang keuangan;

c. Maraknya bisnis yang berbasis teknologi digital, dimana teknologi menunjang perkembangan fintech;

d. Bisnis fintech dianggap lebih fleksibel;

e. Industri keuangan online yang lebih simple bagi pemain usaha start-up; dan

f. Penggunaan social media (memungkinkan industri fintech berkembang karena, data yang di unggah ke media social bisa digunakan untuk menganalisa resiko nasabah).

Menurut Pasal 1 angka 1 peraturan Bank Indonesia Nomor 19/12/PBI/2017 tentang Penyelenggaraan Teknologi Finansial, Fintech merupakan penggunaan teknologi sistem keuangan yang menghasilkan produk, layanan, teknologi, dan/atau model bisnis

\footnotetext{
${ }^{3}$ Marta Widian Sari, A. (2020). Kenali Bisnis Di Era Digital "Financial Technology". Sumatra Barat: CV. Insan Cendekia Mandiri.

${ }^{4}$ Rumondang, A., Sudirman, A., Effendy, F., Simarmata, J., \& Agustin, T. (2019). Fintech: Inovasi Sistem Keuangan di Era Digital . Medan: Yayasan Kita Menulis.

${ }^{5}$ Irawan, D., \& Affan, M. W. (2020). Pengaruh Privasi Dan Keamanan Terhadap Niat Menggunakan Payment Fintceh. Jurnal Kajian Akutansi, 4(1).

${ }^{6}$ Nizar, M. (2017). Teknologi Keuangan (Fintech): Konsep dan Implementasinya di Indonesia. Warta Fiskal, 4(1).

${ }^{7}$ Wasiaturrahma., Ajija, S. R., Sulistyowati, C., \& Farihah, E. (2020). Fintech dan Prospek Bisnis Koperasi Syariah. Surabaya: Scopindo Media Pustaka.
} 
baru serta dapat berdampak pada stabilitas moneter, stabilitas sistem keuangan, efisiensi, kelancaran, keamanan dan keandalan sistem pembayaran.

Penyelenggaraan teknologi finansial yakni meliputi sistem pembayaran, pendukung pasar, manajemen investasi dan manajemen resiko, pinjaman, pembiayaan dan penyedian modal, dan jasa finansial lainnya. Fintech dapat berperan sebagai alat atau teknologi untuk mepermudah proses transaksi antara pembeli dan penjual serta dapat mengurangai celah atau kecurangan dalam proses transaksi tersebut. Fintech juga dapat disebut sebagai sebuah proses pembayaran yang sah tanpa perlu menggunakan instrument kertas (Junadi \& Sfenrianto, 2015). Fintech hadir sebagai pelengkap sistem keuangan yang sudah ada, bukan sebagai pengganti.

Fintech merupakan model bisnis baru yang akan membantu kebutuhan masyarakat dalam melaksanakan transaksi keuangan tanpa harus memiliki rekening seperti perbankan pada umumnya. ${ }^{8}$ Meskipun fintech bukan merupakan lembaga keuangan seperti perbankan namun fintech tetap diatur oleh Bank Indonesia agar konsumen atau masyarakat dapat terlindungi. Oleh karena itu perusahaan penyelenggraan fintech wajib mendaftarkan perusahannya pada Bank Indonesia ataupun Otoritas Jasa Keuangan (OJK). Seiring dengan perkembangan fintech yang terus menggeliat hingga saat ini, tentu harus diimbangi juga dengan hadirnya regulasi dan pengawasan yang jelas terhadap berjalannya fintech tersebut. Kuatnya arus teknologi dalam sistem pembayaran mendorong Bank Indonesia sebagai bank sentral Republik Indonesia untuk memastikan lalu lintas pembayaran yang telah terpenetrasi oleh teknologi tetap berjalan dengan tertib dan aman serta mendukung pilar-pilar dalam pencapaian visi dan misi Bank Indonesia. Bank Indonesia menjamin keamanan dan ketertiban dalam hal lalu lintas pembayaran dengan menjadi :

1) Fasilitator. Bank Indonesia berperan menjadi fasilitator dalam hal penyediaan lahan untuk lalu lintas pembayaran.

2) Analis bisnis yang intelligent. Melalui kerjasama dengan otoritas dengan agen-agen internasional, Bank Indonesia menjadi analis bagi para pelaku usaha terkait Fintech untuk memberikan pandangan dan arahan tentang bagaimana menciptakan sistem pembayaran yang tertib dana man.

3) Asesmen. Bank Indonesia melakukan pengawasan (monitoring) dan penilaian (assessment) terhadap setiap kegiatan usaha yang melibatkan Fintech dan sistem pembayaran menggunakan teknologi.

4) Koordinasi dan Komunikasi. Bank Indonesia senantiasa menjaga hubungan dengan otoritas terkait untuk tetap mendukung keberadaan Fintech sistem pembayaran di Indonesia. Bnak Indonesia juga senantisa berkomitmen untuk mendukung para

\footnotetext{
${ }^{8}$ Chrismastianto, I. A. W. (2017). Analisis SWOT Implementasi Teknologi Finansial Terhadap Kualitas Layanan Perbankan di Indonesia. Jurnal Ekonomi dan Bisnis, 20(1).
} 
pelaku usaha di Indonesia dengan memberikan pengarahan secara berkala mengenai fintech. ${ }^{9}$

Bedasarkan pada Pasal 5 Undang-Undang Nomor 21 Tahun 2011 tentang Otoritas Jasa Keuangan (OJK) yang menyatakan bahwa OJK berfungsi menyelenggarakan sistem pengaturan dan pengawasan yang terintegrasi terhadap keseluruhan kegiatan di dalam sektor jasa keuangan. Pada Pasal 6 menyatakan bahwa OJK melaksanakan tugas pengaturan dan pengawasan terhadap : (a) kegiatan jasa keuangan di sektor Perbankan, (b) kegiatan jasa keuangan di sektor Pasar Modal, dan (c) kegiatan jasa keuangan di sektor Perasuransian, Dana Pensiun, Lembaga Pembiayaan, dan Lembaga Jasa Keuangan lainnya. Apabila mengacu pada kedua pasal ini, OJK adalah instansi yang melakukan pengaturan dan pengawasan terhadap tumbuh kembangnya fintech. Fintech star up termasuk bagian sektor jasa keuangan baik Industri Keuangan Bank maupun Industri Keuangan Non-Bank yang diawasi oleh OJK.

Namun demikian regulasi mengenai Teknologi Finansial di Indonesia belum terlalu jelas sehingga Finansial Teknologi juga mengacu pada Peraturan Bank Indonesia Nomor 18/40/PBI/2016 tentang Penyelenggaraan Pemrosesan Transaksi Pembayaran, Surat Edaran Bank Indonesia Nomor 18/22/DKSP perihal Penyelenggaraan Layanann Keuangan Digital dan Peraturan Bank Indonesia Nomor 18/17/PBI tentang Uang Elektronik. Selain itu, Finansial Teknologi (Fintech) tentu saja harus memenuhi ketentuan umum mengenai perjanjian yang terdapat dalam Pasal 1313 dan Pasal 1338 Kitab Undang-Undang Hukum Perdata (KUHPer) serta syarat sah dalam Pasal 1320 KUHPer. Para pihak dapat melakukan perjanjian dengan menggunakan asas kebebasan berkontrak, artinya hukum perjanjian memberi kebebasan yang seluas-luasnya kepada para pihak untuk mengadakan perjanjian yang berisi apa saja, dengan syarat atau sepanjang perjanjian tersebut tidak melanggar undang-undang, ketertiban umum dan kesusilaan. ${ }^{10}$ Hal ini disebutkan secara tegas dalam Pasal 1337 KUHPer : "Suatu sebab adalah terlarang, jika sebab itu dilarang oleh undang-undang atau bila sebab itu bertentangan dengan kesusilaan atau dengan ketertiban umum."

Pengaturan dan pengawasan menjadi sangat penting bagi keberlangsungan fintech yang ada di Indonesia. Hal ini berkaitan dengan legalitas dari bisnis yang dijalankan karena pada pelaksanan pengembangan fintech memiliki potensi risiko yakni berkaitan dengan perlindungan konsumen, stabilitas sistem keuangan, sistem pembayaran dan stabilitas ekonomi. ${ }^{11}$ Tujuan pengaturan dan pengawasan oleh OJK adalah untuk meminimalisir risiko tersebut dan menunjang pertumbuhan ekonomi yang berkelanjutan dan stabil.

\footnotetext{
${ }^{9}$ Marginingsih, R. (2019). Analisis SWOT Technology Financial (Fintech) Terhadap Industri Perbankan. Jurnal Humaniora, 19(1), hlm. 56.

${ }^{10}$ Raharjo, H. (2009). Hukum Perjanjian di Indonesia. Yogyakarta: Pustaka Yustisia.

${ }^{11}$ Rusdianasari F. (2018). Peran Inklusi Keuangan melalui Integrasi Fintech dalam Stabilitas Sistem Keuangan Indonesia. Jurnal Ekonomi Kuantitatif Terapan, 11(2).
} 
Pengawasan terhadap fintech ini harus mendapat perhatian yang khusus terutama terkait dengan produk dan perlindungan hukum karena layanan keuangan yang ditawarkan oleh fintech ini berbasis online dan adanya kejelasan mengenai siapa saja yang terkait dengan para pihak yang melakukan perjanjian kerjasama melalui fintech. ${ }^{12}$ Selain itu kedudukan penyelenggara dalam fintech tidak jelas karena hanya sebagai penghubung yang mempertemukan para pihak yang bersangkutan, sementara klausulklausul perjanjian tetap pada kesepakatan kedua belah pihak yang syarat-syarat materil maupun formilnya telah ditentukan oleh peraturan perundang-undangan. ${ }^{13}$

Naskah ini berisi tentang kajian tinjauan yuridis transaksi financial technology (fintech) di Indonesia dan mengetahui permasalahan yang terkait dengan kedudukan hukum para pihak dalam transaksi Financial Technology di Indonesia.

\section{Metode Penelitian}

Jenis peneitian yang digunakan dalam penelitian ini adalah penelitian nomatif. Penelitian normatif menjadikan sistem norma dan aturan hukum sebagai pusat kajian yang dikaitkan dengan peristiwa hukum. ${ }^{14}$ Data yang digunakan dalam penelitian adalah data sekunder, yang terdiri atas buku atau jurnal hukum yang berisi mengenai prinsip hukum, hasil penelitian hukum dan lainnya yang terkait dengan naskah ini. Studi kepustakaan digunakan sebagai teknik dalam memperoleh data, yang selanjutnya di oleh dengan metode analisis deskriptif untuk medapatkan kesimulan.

\section{Hasil dan Pembahasan}

\section{A. Kedudukan hukum para pihak dalam transaksi fintech di Indonesia}

Secara umum para pihak dalam financial technology yakni penyelenggara pada bisnis fintech, setiap pihak yang ikut serta dalam penyelenggaraan fintech dan pengguna layanan fintech. Perjanjian pada fintech seyogyanya sama dengan perjanjian pada umumnya, dimana perjanjian yang diselenggarakan harus memenuhi syarat-syarat sahnya perjanjian yang salah satunya adalah kesepakatan para pihak. ${ }^{15}$ Kesepakatan para pihak merupakan syarat subjektif yang patut di penuhi, jika tidak maka perjanjian tersebut batal demi hukum.

\footnotetext{
${ }^{12}$ Serfiyani, C. Y., Purnomo, R. S. D., \& Hariyani, I. (2013). Buku Pintar Bisnis Online dan Transaksi Elektronik . Jakarta: Gramedia Pustaka Utama.

${ }^{13}$ Ariyani, E. (2013). Hukum Perjanjian. Yogyakarta: Penerbit Ombak.

${ }^{14}$ Fajar, M \& Achmad, Y. (2017). Dualisme Penelitian Hukum Normatif \& Empiris. Yogyakarta: Pustaka Pelajar, h. 36.

15 Paath, D. K. (2019). Analisis Persepsi Pengguna Layanan Transaksi Digital Terhadap Financial Technology (Fintech) Dengan Model E-Money (Studi kasus: layanan Go-Pay "Gojek" di Purwokerto). Jurnal HUMMANSI (Humaniora, Manajemen, Akuntansi), 2(2).
} 


\section{Penyelenggara}

Menurut Pasal 1 Angka 2 Peraturan BI No. 19/12.PBI/2017 Penyelenggara adalah setiap pihak yang yang menyelenggarakan kegiatan Teknologi Finansial. Sedangkan dalam Pasal 1 angka 6 POJK No. 77/POJK.01/2016 menjelaskan bahwa penyelenggara adalah badan hukum Indonesia yang menyediakan, mengelola dan mengoperasikan layanan pinjam meminjam uang berbasis teknologi informasi. ${ }^{16}$ Penyelenggara dalam hal ini sebagai Lembaga Jasa Keuangan lainnya yang berbentuk badan hukum dapat berupa perseroan terbatas atau koperasi. Untuk itu penyelenggara dalam transakasi fintceh wajib untuk mengajukan pendaftaran serta perizinan kepada Otoritas Jasa Keuangan (OJK). Dalam Pasal 2 Peraturan BI No. 19/12.PBI/2017 mengatur penyelenggara Teknologi Finansial untuk mendorong inovasi di bidang keuangan dengan menerapkan prinsip perlindungan konsumen serta manajemen risiko dan kehati-hatian guna tetap menjaga stabilitas moneter, stabilitas system keuangan, dan sistem pembayaran yang efisien, lancar, aman, dana andal.

\section{Pemberi pinjaman}

Mengenai pemberi pinjaman dijelaskan dalam Pasal angka 8 POJK No. 77/POJK.01/2016 bahwa pemberi pinjaman adalah orang, badan hukum, dan/atau badan usaha yang mempunyai piutang terkait perjanjian layanan pinjam meminjam berbasis teknologi informasi. Dalam hal ini pemberi pinjaman merupakan pihak yang akan memberikan pinjaman kepada penerima pinjaman dan akan dipertemukan oleh penyelenggara. ${ }^{17}$

\section{Penerima pinjaman}

Dalam Pasal 1 angka 7 POJK No. 77/POJK.01/2016 menjelaskan bahwa penerima pinjaman adalah orang, dan/atau badan hukum yang memiliki utang karena perjanjian layanan pinjam-meminjam uang berbasis teknologi informasi. Penyelenggara akan mempertemukan penerima pinjaman dengan pemberi pinjaman melalui website aplikasi finansial teknologi yang sudah terdaftar dalam OJK.

\section{B. Perjanjian dan/kontrak para pihak dalam transaksi fintech di Indonesia}

Perjanjian dan/atau kontrak elektronik yang dibentuk oleh para pihak akan menimbulkan hubungan hukum, yang mana hubungan hukum tersebut lahir dari perjanjian para pihak, baik bagi si pemberi pinjaman, penerima pinjam dan penyelenggara layanan finansial teknologi. Terkait hubungan hukum para pihak, terdapat berbagai perjanjian.

\footnotetext{
${ }^{16}$ Santi, E., Budiharto., \& Saptono, H. (2017). Pengawasan Otoritas Jasa Keuangan Terhadap Financial Technology (Peraturan Otoritas Jasa Keuangan Nomor 77/POJK.01/2016). Diponegoro Law Journal, 6(3).

${ }^{17}$ Radita, C. (2018). Tanggung Gugat Penyelenggara Peer to Peer Landing Jika Penerima Pinjaman Melakukan Wanprestasi. Jurnal Juris-Duction, 1(2)
} 


\section{Perjanjian antara pemberi pinjaman dengan penyelenggara}

Penyelenggaara dalam laman perusahaan fintceh yang dikelolanya dapat menawarkan kepada masyarakat luas untuk berinvestasi dengan mengambil posisi sebagai pemberi pinjaman. Kemudian jika si calon pemberi pinjaman merasa tertarik untuk memberika pinjamannya, maka si pemberi pinjaman dengan penyelenggara akan timbul suatu perjanjian yang dituangkan dalam dokumen elektronik antara para pihak. Timbulnya suatu perjanjian karena pemberi pinjaman mengikatkan dirinya pada penyelenggara untuk memberikan pinjaman terhadap tawaran yang dilakukan oleh penerima pinjaman yang telah diajukan melalui laman penyelenggara. Setelah penerima pinjaman menyetujui segala ketentuan-ketentuan yang telah ditentukan oleh penyelenggara maka pemberi pinjaman sepakat untuk memberikan kuasa pada lama finansial teknologi untuk memberikan pinjaman terhadap si penerima pinjaman. Bentuk kesepakatan untuk memberikan kuasa antara pemberi pinjaman serta penyelenggara yakni pada saat pemberi pinjemen telah menyetujui seluruh syarat dan berbagai ketentuan yang diberikan penyelenggara, kemudian pemberi pinjaman menyatakan persesuaian kehendak. Informasi penggunaan dana yang diberikan oleh penyelenggara paling sedikit harus memuat :

1. Jumlah dana yang dipinjamkan kepada penerima pinjaman;

2. Tujuan pemanfaatan dana oleh penerima pinjaman;

3. Besaran bunga pinjaman; dan

4. Jangka waktu pinjaman

\section{Perjanjian antara penerima pinjaman dengan penyelenggara}

Hubungan hukum yang timbul antara penyelenggara dengan penerima pinjaman dalam bentuk perjanjiaan berupa perjanjian pengguna layanan finansial teknologi. Lahirnya perjanjian tersebut apabila penerima pinjaman telah menyetujui terkait dengan ketentuan dan syarat-syarat pengguna yang telah ditetapkan oleh penyelenggara. Perjanjian antara penyelenggara dan penerima pinjaman telah terikat dengan adanya proses pinjaman yang akan didapatkan oleh pinjaman oleh penerima pinjaman darai pemberi pinjaman melalui penyelenggara. Untuk ini dalam perjanjian tersebut dianggap sebagai awal perjanjian pinjam-meminjam.

\section{Perjanjian antara penerima pinjaman dan pemberi pinjaman}

Para pihak antara pemberi pinjaman dan penerima pinjaman dalam sistem financial technology tidak saling bertemu secara langsung, dalam hal ini penerima pinjaman untuk mendapatkan pinjamannya cukup membuka aplikasi pinjaman online dan mengisi formulir pinjam online, hubungan pinjam-meminjam yang terjadi adalah antara pemberi pinjaman dan penerima pinjaman. Antara pemberi pinjaman dan penerima 
pinjaman terdapat hubungan hukum dalam bentuk perjanjian pemberian pinjaman/perjanjian pinjam-meminjam. ${ }^{18}$

Dalam sistem financial technology, penyaluran pinjaman kepada penerima pinjaman bukan antara penyelenggara dan penerima pinjaman melainkan antara pemberi pinjaman dan penerima pinjaman. Untuk mewujudkan hal ini, pemberi pinjaman harus memberikan kuasa dengan tegas kepada penyelenggara untuk menyalurkan dananya kepada penerima pinjaman melalui escrow account dan virtual account. Penerima pinjaman yang akan melunasi pinjamannya dalam hal ini seharusnya dapat langsung membayarkannya melalui escrow account penyelenggara untuk diteruskan ke virtual account milik pemberi pinjaman mengingat hubungan hukum atas perjanjian pinjam meminjam terjadi antara pemberi pinjaman dan penerima pinjaman.

Dalam Pasal 1754 KUHPdt Pinjam meminjam adalah suatu perjanjian dengan mana pihak yang satu memberikan kepada pihak yang lain suatu jumlah tertentu barangbarang yang habis karena pemakaian, dengan syarat bahwa pihak yang meminjam akan mengembalikan sejumlah yang sama dari barang-barang tersebut. Perjanjian yang antara pemberi pinjaman dengan penerima pinjaman menimbulkan hubungan hukum. Hubungan hukum tersebut melahirkan hak dan kewajiban bagi para pihak agar dapat dilaksanakan. Adapun kewajiban pemberi pinjaman yaitu tidak boleh meminta kembali apa yang telah dipinjamkannya sebelum lewatnya waktu yang ditentukan dalam perjanjian. Kemudian hak pemberi pinjaman adalah mendapatkan pengembalian pinjaman beserta dengan bunga dalam jangka waktu yang ditentukan.

Sementara kewajiban penerima pinjaman adalah wajib mengembalikan barang dalam jumlah dan keadaan yang sama pada waktu yang ditentukan. Kewajiban lain dari si penerima pinjaman yaitu jika penerima pinjaman tidak mampu mengembalikan barang yang dipinjamnya dalam jumlah dan keadaan yang sama, maka ia diwajibkan membayar harganya, dalam hal mana harus diperhatikan waktu dan tempat dimana barangnya, menurut perjanjian harus dikembalikan. Jika waktu dan tempat ini tidak telah ditetapkan, harus diambil harga barang pada waktu dan tempat dimana perjanjian telah terjadi (Pasal 1764 KUHPerdata); dan jika telah diperjanjikan bunga, maka bunga yang telah diperjanjikan tersebut harus dibayar sampai saat pengembalian atau penitipan uang pokoknya (Pasal 1766 KUHPerdata). Kemudian hak dari penerima pinjam adalah mendapatkan pinjaman atau pendanaan dari pemberi kewajiban dari penerima pinjaman adalah mengembalikan pinjaman pinjaman.

\section{Perjanjian antara penyelenggara dan OJK}

Hubungan hukum antara penyelenggara dan OJK lahir atas dasar ketentuan peraturan perundang-undangan dalam hal ini POJK No. 77/POJK.01/2016 tentang Layanan Pinjam Meminjam Berbasis Teknologi Informasi. Berdasarkan ketentuan POJK ini, penyelenggara yang bermaksud menjalankan penyelenggaraan sistem financial

${ }^{18}$ Wijayanto, H., Muhammad, A. H., \& Hariyadi, D. (2020). Analisis Penyalahgunaan Data Pribadi Dalam Aplikasi Fintech Ilegal Dengan Metode Hibrid. Jurnal Ilmiah Sinus, 18(1). 
technology harus mendapatkan izin dari OJK dan setelah menjalankan sistem finansial technology harus memberikan laporan berkala ke OJK. Berdasarkan ketentuan tersebut, jelas penyelenggaraan fintech harus seizin dan dibawah pengawasan OJK. Hubungan hukum antara penyelenggara fintech dan OJK adalah hubungan hukum yang lahir dari ketentuan peraturan perundang-undangan bukan atas dasar perjanjian. OJK sebagai lembaga independen yang dibentuk berdasarkan undang-undang memiliki kapasitas sebagai pengawas kegiatan usaha yang dijalankan oleh Lembaga Jasa Keuangan (LJK). Hal ini ditujukan untuk mewujudkan kepastian hukum dan perlindungan hukum bagi para pihak.

Suatu kontrak elektronik sah apabila memenuhi Pasal 46 ayat (2), Peraturan Pemerintah No.71 Tahun 2019 tentang Penyelenggaraan Sistem dan Transaksi Elektronik, yaitu :

1) terdapat kesepakatan para pihak;

2) dilakukan oleh subjek hukum yang cakap atau yang berwenang mewakili sesuai dengan ketentuan peraturan perundang-undangan;

3) terdapat hal tertentu; dan

4) objek transaksi tidak boleh betentangan dengan peraturan perundang-undangan, kesusilaan, dan ketertiban umum.

Syarat sah perjanjian elektronik ini sejalan dengan ketentuan dalam Pasal 1320 KUHPerdata. Dalam fintech perjanjian elektronik berisi hak dan kewajiban dari para pihak. Berdasarkan pada Pasal 30 POJK No. 13 Tahun 2018, kewajban yaitu: penyelenggara wajib menjaga kerahasiaan, keutuhan, dan ketersediaan data pribadi, data transaksi, dan data keuangan yang dikelolanya sejak data diperoleh hingga data tersebut dimusnahkan; pemanfaatan data dan informasi pengguna oleh penyelenggara harus memperoleh persetujuan dari pengguna, menyampaikan batasan pemanfaatan data dan informasi kepada pengguna, menyampaikan setiap adanya perubahan tujuan pemanfaatan data kepada pengguna dalam hal ada perubahan tujuan pemanfaatan data, media dan metode yang dipergunakan dalam memperoleh data dan informasi terjanim kerahasiaan, keamanan, serta keutuhannya. Penyelenggara fintech berhak utuk memastikan adanya itikad baik konsumen dan mendapatkan informasi dan/atau dokumen mengenai konsumen yang akurat, jujur, jelas, dan tidak menyimpang. ${ }^{19}$

Sedangkan kewajiban dari pengguna jasa fintech yakni memberikan data atau informasi pribadi yang benar kepada penyelenggara fintech, dengan cara mengisi formulir elektronik yang telah disediakan penyelenggara. Kemudian hak konsumen fintech adalah mendapatkan Lembaga Jasa Keuangan yang ditawarkan oleh perusahaan fintech dan mendapatkan jaminan perlindungan hukum atas segala keamanan data pribadi yang telah diserahkan kepada penyelenggara fintech.

\footnotetext{
${ }^{19}$ Sari, M. W., \& Novrianto, A. (2020). Kenali Bisnis Di Era Digital "Financial Technology. Sumatra Barat: CV. Insan Cendekia Mandiri.
} 


\section{Hubungan para pihak dalam transaksi fintech di Indonesia}

Hubungan hukum di dalam fintech berdasarkan POJK No. 77/POJK.01/201 tentang Layanan Pinjam Meminjam Uang Berbasis Teknologi Informasi (LPMUBT) timbul karena perjanjian pinjam meminjam uang. Pinjam-meminjam menurut Pasal 1754 KUH Perdata adalah suatu perjanjian dengan mana pihak yang satu memberikan kepada pihak yang lain suatu jumlah tertentu barang-barang yang habis karena pemakaian, dengan syarat bahwa pihak yang terakhir ini akan mengembalikan sejumlah yang sama dari jenis dan mutu yang sama pula. Subjek dalam perjanjian pinjam-meminjam uang adalah pemberi pinjaman (kreditur) dan penerima pinjaman (debitur). Sementara objek dalam perjanjian pinjam meminjam uang adalah semua barang-barang yang habis dipakai dengan syarat barang tersebut harus tidak bertentangan dengan undang-undangan, kesusilaan, dan ketertiban umum. ${ }^{20}$

\section{Hubungan hukum para pihak dalam bisnis financial tecnology (fintech)}

Bisnis fintech atau Inovasi Keuangan Digital dalam Pasal 1 angka 1 POJK No.13 Tahun 2018 merupakn aktivitas pembaruan proses bisnis, model bisnis, dan instrumen keuangan yang memberikan nilai tambah baru di sektor jasa keuangan. Meskipun OJK telah mengetahui bahwa ada sedikitnya delapan jenis fintech yang telah berkembang di Indonesia, namun hanya satu jenis bisnis fintech saja yang telah memiliki aturan khusus dari OJK, yakni jenis fintech pinjam meminjam berbasis aplikasi teknologi (P2P Lending). Hubungan hukum dalam aturan OJK Nomor 13/POJK.12/2018 tentang Inovasi Keuangan Digital di Sektor Jasa Keuangan, yakni mengatur hubungan antara penyelenggara dan konsumen Inovasi Keuangan Digital. ${ }^{21}$ Hal ini sesuai dengan ketentuan Pasal 30 mengenai Perlindungan Kerahasiaan Data. Pasal 30 tersebut mengatur tentang kewajiban penyelenggara fintech untuk melindungi data konsumennya. Untuk itu dalam POJK No. 13/POJK.02/2018 dalam kaitannya mengenai hubungan hukum, hanya mengatur hubungan hukum penyelenggara dan pengguna fintech

\section{Terjadinya hubungan hukum dalam bisnis financial technology (fintech)}

Terjadinya hubungan hukum dalam perjanjian fintech ketika disetujuinya suatu perjanjian elektronik atau biasa dikenal dengan kontrak elektronik. Secara konvensional perjanjian dapat terjadi melalui pertemuan langsung ataupun tidak langsung dari kedua belah pihak yang masing-masing berperan dan bertindak untuk atas nama dirinya sendiri atau bertindak sebagai atas nama sebuah perusahaan yang diwakilinya, dimana pihak pertama telah melakukan penawaran (offeror) dan diterima oleh penerima (offeree) dengan ketentuan-ketentuan hukum yang jelas serta bertujuan menciptakan suatu hubungan hukum (rechtsbetrekking).

\footnotetext{
${ }^{20}$ Tutik, T. T . (2006). Pengantar Hukum Perdata di Indonesia (Rina (ed)). Jakarta: Prestasi Pustaka.

${ }^{21}$ Hariyani, I. \& Yustisia, C. (2017). Perlindungan Hukum Bagi Pemberi Pinjaman Berbasis Peer To Peer Lending di Indonesia. Jurnal Legalisasi Indonesia, 14(3).
} 
Dalam bisnis fintech suatu hubungan hukum terjadi karena adanya kontrak atau perjanjian, namun dalam konteks bisnis fintech terjadi karena adanya perjanjian elektronik. Menurut UU ITE perjanjian online atau kontrak elektronik adalah perjanjian para pihak yang dibuat melalui sistem elektronik. Untuk kita dapat dipahami bahwa perjanjian elektronik merupakan perjanjian yang lahir atau sebagian lahir dengan bantuan dan fasilitas jaringan komputer yang saling terhubung, dimana perjanjian tersebut dimuat dalam dokumen elektronik dan media elektronik lainnya.

\section{Penawaran dalam financial technology (fintech) dilakukan secara online}

Penawaran (offer) adalah suatu komunikasi yang dilakukan oleh pihak yang menawarkan sesuatu (offeror) dengan pihak yang ditawarkan sesuatu (offerer), dimana rangkaian kata-kata atau tindakan membentuk adanya perjanjian dengan adanya penerimaan. $^{22}$ Dalam konteks online, sebuah jasa online lainnya dapat memajang informasi produk yang ditawarkan kepada konsumen. Informasi tersebut dapat berupa katalog produk dan layanan yang mereka berikan yang disertai dengan berbagai informasi seperti harga, spesifikasi barang, nilai rating produk atau jasa perusahaan pembuat, dan lain-lain. Sama halnya dengan bisnis Fintech, yang menawarkan produk dan layanannya disertai dengan berbagai informasi seperti harga, spesifikasi barang, nilai rating produk atau jasa perusahaan pembuat, dan lain-lain, kepada konsumennya secara online.

\section{Penerimaan financial technology (fintech) dilakukan secara online}

Penerimaan ialah suatu komunikasi yang dilakukan oleh pihak yang ditawarkan sesuatu kepada pihak yang menawarkan sesuatu dimana rangkaian kata-kata atau tindakan yang dilakukan secara objektif dapat diartikan menyetujui penawaran. Tanpa adanya suatu penerimaan terhadap suatu penawaran maka tidak akan mungkin lahir suatu kontrak. Biasanya penerimaan diilakukan dengan cara-cara yang telah ditentukan oleh pihak yang menawarkan sesuatu. Terdapat dua metode pokok komunikasi yang digunakan pada tahapan lahirnya sebuah kontrak di internet, yakni e-mail dan webpage atau click wap. Penawaran dan penerimaan dalam fintech yang dilakukan secara elektronik biisa melalui $e$-mail atau webpage.

\section{Kontrak elektronik (e-contract) dalam bisnis fintech}

Kontrak elektronik merupakan dasar hubungann hukum para pihak dalam bisniss fintech. Secara "tradisional" suatuu perjanjain atau kontrak dibuat dengan berlandaskan kebebasan berkontrak diantara dua pihak yang memiliki kedudukan seimbang. Perbedaan antara kontrak elektronik dan kontrak pada umumnya ialah kontrak elektronik dibuat melalui sistem elektronik, seperti yang terdapat dalam Pasal 1 angka 17 UU ITE yang menyatakan bahwa "Kontrak Elektronik adalah perjanjian para pihak yang dibuat melalui sistem elektronik”. Sedangkan kontrak pada umumnya tidak melalui sistem elektronik.

\footnotetext{
${ }^{22}$ Niniek Suparni, 2009, Cyber Space Problematika Antisipasi Pengaturannya, Sinar Grafika; Jakarta, 2009, hlm. 105.
} 
Kontrak elektronik dalam perjanjian fintech dilakukan oleh penyelenggara dan konsumen. Penyelenggara dalam hal ini adalah pengirim informasi elektronik dan/atau dokumen elektronik. Sedangkan konsumen ialah penerima informasi dan/atau dokumen elektronik. Penyelenggara dana konsumen melakukan hubungan hukum dilandasi oleh adanya perjanjian antara para pihak, perjanjian inilah yang disebut dengan kontrak elektronik.

\section{Lahirnya kontrak elektronik dalam bisnis fintech}

Bisa diketahiu bahwa secara umum suatu kontrak akan lahir saat adanya penerimaan terhadap suatu penawaran. Hal tersebut tidak jauh berbeda dengan kontrak elektronik, lahirnya kontrak elektronik pada prinsipnya memiliki kesamaan dengan kontrak konvensional. Perjanjian elektronik dalam fintech, lahir melalui websitenya yang telah menyediakan formulir jasa keuangan atau produk keuangan yang bisa diisi secara langsung oleh calon debitur sesuai dengan dibutuhkan atau calon debitur membuka akun kemudian mendaftarkan diri menjadi anggota sebelum mendapatkan formulir dan melakukan verifikasi data melalui $e$-mail.

Hubungan hukum antara penyelenggara dan pengguna fintech dalam hal ini terjadi karena disetujuinya suatu perjanjian elektronik. Dimana perjanjian elektronik dalam fintech berisi hak dan kewajiban para pihak. Kewajiban penyelenggara fintech disini berdasarkan Pasal 30 POJK tahun 2018 yaitu "Penyelenggara wajib menjaga kerahasiaan, keutuhan, dan ketersediaan data pribadi, data transaksi, dan data keuangan yang dikelolanya sejak data diperoleh hingga data tersebut dimusnahkan. Untuk pemanfaatan data dan informasi pengguna yang diperoleh penyelenggara harus mendapatkan persetujuan dari pengguna, menyampaikan batasan pemenfaatan data dan informasi kepada pengguna, menyampaikan jika ada perubahan tujuan pemanfaatan data dan informasi media dan metode yang dipergunakan dalam memperoleh data dan informasi, terjamin segala kerahasian, keamanan, serta keutuhannya. ${ }^{23}$

Sedangkan kewajiban pengguna jasa fintech adalah memberikan data atau informasi pribadi yang benar kepada penyelenggara bisnis fintech. Hak dari pengguna fintech ialah mendapatkan layanan jasa keuangan yang ditawarkan oleh penyelenggara fintceh dan mendapatkan jaminan perlindungan hukum atas keamanan data pribadi mereka yang telah diserahkan. ${ }^{24}$

\section{Simpulan}

Peraturan mengenai fintech tertuang dalam Peraturan Bank Indonesia Nomor 19/12/PBI/2017 Tahun 2017 tentang Penyelenggaraan Teknologi Finansial. Secara garis

\footnotetext{
${ }^{23}$ Mansur, D. M. A., \& Gultom, E. (2009). Cyber Law Aspek Hukum Teknologi Informasi. Jakarta: PT. Refika Aditama.

${ }^{24}$ Yudha, A. T. R. T., dkk. (2020). Fintceh Syariah : Teori dan Terapan. Surabaya: Scopindo Media Pustaka
} 
besar fintech merupakan penggunaan teknologi dalam system keuangan yang menghasilkan berbagai produk, layanan serta model bisnis baru yang terdiri atas beberapa jenis kegiatan. Fintech memiliki banyak manfaat yang paling utama ialah efektivitas dan efisiensi yang dibutuhkan masyarakat. Namun jika adanya manfaat maka tidak terlepas pula dari adanya kekurangan.

Hubungan hukum para pihak dalam fintech dapat terjadi karena adanya suatu perjanjian, ada tiga (3) macam perjanjian yang timbul yakni perjanjian penggunan layanan, perjanjin penyelenggara dan perjanjian pemberian pinjaman. Dengan adanya perjanjian-perjanjian tersebut mengakibatkan hubungan hukum berupa :

1) Perjanjian Antara Pemberi Pinjaman dengan Penyelenggara;

2) Perjanjian Antara Penerima Pinjaman dengan Penyelenggara;

3) Perjanjian Antara Pemberi Pinjaman dan Penerima Pinjaman, dan

4) Perjanjian Antara Penyelenggara dengan OJK.

Perjanjian tersebut dibentuk dan dilaksanakan berdasarkan ketentuan-ketentuan hukum yang berlaku serta kesepakatan para pihak. Perjanjian ini juga yang menjadi tanda bahwa para pihak telah terikat dalam suatu hubungan hukum yang kemudian menghsilkan hak dan kewajiban diantara para pihak. Hak dan kewajiban inilah yang menjadi simbol kedudukan para pihak, dan masing-masing pihak memiliki peran sesuai dengan kedudukan hukumnya.

\section{Daftar Pustaka}

\section{Buku}

Adiningsih, S. (2019). Transformasi Ekonomi Berbasis Digital di Indonesia. Jakarta: PT Gramedia Pustaka Utama.

Ariyani, E. (2013). Hukum Perjanjian. Yogyakarta: Penerbit Ombak.

Fajar, M., \& Achmad, Y. (2017). Dualisme Penelitian Hukum Normatif \& Empiris. Yogyakarta: Pustaka Pelajar, h. 36.

Raharjo, H. (2009). Hukum Perjanjian di Indonesia. Yogyakarta: Pustaka Yustisia.

Mansur, D. M. A., \& Gultom, E. (2009). Cyber Law Aspek Hukum Teknologi Informasi. Jakarta: PT. Refika Aditama.

Rahadi, D. R. (2020). Financial Technology. PT: Filda Fikrindo.

Rumondang, A., Sudirman, A., Effendy, F., Simarmata, J., \& Agustin, T. (2019). Fintech: Inovasi Sistem Keuangan di Era Digital . Medan: Yayasan Kita Menulis.

Sari, M. W., \& Novrianto, A. (2020). Kenali Bisnis Di Era Digital "Financial Technology. Sumatra Barat: CV. Insan Cendekia Mandiri. 
Serfiyani, C. Y., Purnomo, R. S. D., \& Hariyani, I. (2013). Buku Pintar Bisnis Online dan Transaksi Elektronik. Jakarta: Gramedia Pustaka Utama.

Tutik, T. T . (2006). Pengantar Hukum Perdata di Indonesia (Rina (ed)). Jakarta: Prestasi Pustaka.

Wasiaturrahma., Ajija, S. R., Sulistyowati, C., \& Farihah, E. (2020). Fintech dan Prospek Bisnis Koperasi Syariah. Surabaya: Scopindo Media Pustaka.

Yudha, A. T. R. T., dkk. (2020). Fintceh Syariah : Teori dan Terapan. Surabaya: Scopindo Media Pustaka.

\section{Jurnal}

Chrismastianto, I. A. W. (2017). Analisis SWOT Implementasi Teknologi Finansial Terhadap Kualitas Layanan Perbankan di Indonesia. Jurnal Ekonomi dan Bisnis, 20(1).

Irawan, D., \& Affan, M. W. (2020). Pengaruh Privasi Dan Keamanan Terhadap Niat Menggunakan Payment Fintceh. Jurnal Kajian Akutansi, 4(1).

Hariyani, I. \& Yustisia, C. (2017). Perlindungan Hukum Bagi Pemberi Pinjaman Berbasis Peer To Peer Lending di Indonesia. Jurnal Legalisasi Indonesia, 14(3).

Wijayanto, H., Muhammad, A. H., \& Hariyadi, D. (2020). Analisis Penyalahgunaan Data Pribadi Dalam Aplikasi Fintech Ilegal Dengan Metode Hibrid. Jurnal Ilmiah Sinus, 18(1).

Marginingsih, R. (2019). Analisis SWOT Technology Financial (Fintech) Terhadap Industri Perbankan. Jurnal Humaniora, 19(1).

Nizar, M. (2017). Teknologi Keuangan (Fintech): Konsep dan Implementasinya di Indonesia. Warta Fiskal, 4(1).

Paath, D. K. (2019). Analisis Persepsi Pengguna Layanan Transaksi Digital Terhadap Financial Technology (Fintech) Dengan Model E-Money (Studi kasus: layanan Go-Pay “Gojek” di Purwokerto). Jurnal HUMMANSI (Humaniora, Manajemen, Akuntansi), 2(2).

Radita, C. (2018). Tanggung Gugat Penyelenggara Peer to Peer Landing Jika Penerima Pinjaman Melakukan Wanprestasi. Jurnal Juris-Duction, 1(2) .

Rusdianasari F. (2018). Peran Inklusi Keuangan melalui Integrasi Fintech dalam Stabilitas Sistem Keuangan Indonesia. Jurnal Ekonomi Kuantitatif Terapan, 11(2). 
Santi, E., Budiharto., \& Saptono, H. (2017). Pengawasan Otoritas Jasa Keuangan Terhadap Financial Technology (Peraturan Otoritas Jasa Keuangan Nomor 77/POJK.01/2016). Diponegoro Law Journal, 6(3). 